〈報 告〉

\title{
$\lceil\mathrm{WHO}$ 手指衛生改善のための多角的戦略」を活用した 重症心身障害児（者）病棟における手指衛生改善の取り組み \\ 鈴木 由美・森野 誠子・山本 重則・篠㟝 文信
}

\section{Implementation of the World Health Organization Multimodal Hand Hygiene Improvement Strategy in SMID (Severe Motor and Intellectual Disabilities) Patients' Wards in Japan}

Yumi SuZUki, Motoko Morino, Shigenori Yamamoto and Fuminobu ShinOZAKI

National Hospital Organization Shimoshizu Hospital

(2017 年 7 月 13 日受付・ 2018 年 5 月 2 日受理)

\begin{abstract}
要 旨
近年の重症心身障害児（者）病棟（以下，重症児（者）病棟）には人工呼吸器使用者など多剂耐 性菌保菌リスクの高い重症児が多く, 感染対策は重要である。一方, 家庭的な風土の中, 介助員・ 保育士等の非医療職も含めた多職種が直接患者のケアを行っている.このような状況下, 当院のこ れらの病棟でのアルコール手指衛生剤（以下 AHR）使用量は大変少なかった。このため 2014 年度 から WHO「手指衛生改善のための多角的戦略」を採用し，「段階的アプローチ」に則り「多角的 戦略の 5 つの構成要素」を活用して病院全体として改善に取り組んだ。その結果, 重症児（者）病 棟 A (60 床) における年間平均 AHR 使用量は 2.9 (2012 年) $\rightarrow 4.2$ (2013 年) $\rightarrow 10.1$ (2014 年) $\rightarrow 15.0$ (2015 年) $\rightarrow 26.7 \mathrm{~L} / 1000$ 患者/日（2016 年）, 同病棟 B (60 床) で $2.2 \rightarrow 2.8 \rightarrow 5.5 \rightarrow 11.8 \rightarrow 18.6 \mathrm{~L} / 1000$ 患者/日と増加した．本戦略の 3 つの要素のうち「5つの瞬間」がよく知られているが, 取り組み の開始と継続の方法を具体的に示す「段階的アプローチ」も, スムーズな導入と持続的な改善のた めに重要と考えられた。 また「多角的戦略の 5 つの構成要素」や「自己評価フレームワーク」の項 目を，システムやハードの整備を優先し，自施設に合わせた工夫をして取り組むことは手指衛生の 改善に効果的と考えられた.
\end{abstract}

Key words : 手指衛生, 重症心身障害児（者）病棟, WHO 手指衛生改善のための多角的戦略

序文

I 背 景

重症心身障害児 (者) 病棟（以下，重症児（者）病棟） は元来生活自立度の低い患者の集団生活の場であり, 家 庭的な風土がある。近年は経管栄養や気管切開, 人工呼 吸器等, 非常に濃厚なケアや医療を常時必要とする超重 症児（者）が増加しており, 死亡退院まで数十年間在院 する患者も多い ${ }^{1)}$ 。一方で, 新生児集中治療室からの超 重症児の新規入院受け入れや短期入所も近年増加してい $ろ^{2)}$. 重症児は感染症に罹患した場合の予備力が少ない だけでなく，重症児以外の患児と比較して耐性菌の検出 頻度が有意に高いとされている ${ }^{3)}$. 猪飼らは重症心身障

国立病院機構下志津病院
害児の療育にあたって，メチシリン耐性黄色ブドウ球菌 (Methicillin resistant Staphylococcus aureus : MRSA) の伝播防止には, 厳重な隔離より手指衛生をはじめとす る標準予防策の徹底が有用であったと報告している 寺島らは, 重症児 (者) 病棟では医師, 看護師以外にも 訓練士，保育士，教員などがそれぞれ異なるケアを担っ ているため，教育背景が異なる多職種それぞれに対して， 手指衛生について教育的な働きかけを行う必要があると 述べている ${ }^{5}$. 多剤耐性菌が蔓延する現在, 十分な手指 衛生の実践は, 重症児 (者) 病棟における重要課題の一 つである. 当院での重症児（者）病棟の手指衛生意識は 低く, 手指衛生の啓発が必要であると感じていた中, 2014 年度に重症児 (者) 病棟 Aにおいて 2 系統耐性アシネ トバクター (2 drugs resistant Acinetobacter baumanii 
以下 2DRA）の院内新規発生の集積を経験した. 環境調 査では病院環境や共用する医療器材からの菌の検出はな く手指衛生不足が主な原因と考えられたため, 同年度か ら病院をあげて世界保健機関（World Health Organization：WHO）「手指衛生改善のための多角的戦略」：以 下「WHO 手指衛生多角的戦略 ل卓を用い, 組織的かつ多 角的に手指衛生に取り組んだ.

本戦略について国内でもいくつか実施報告はあるが, その多くは「手指衛生 5 つの瞬間」を活用したもので7 9), 多角的な戦略を構成する 3 つの要素すべてを実践した報 告はない，海外からの報告 ${ }^{10,11)} も$ あが，その多くは単 年に限られた活動の報告である。また，これまでの報告 では手指衛生改善の取り組みの効果について, MRSA 感染症発生数もしくは新規発生数をアウトカム評価とし ていることが多い年 ${ }^{17)}$. しかし重症児（者）病棟におい ては，保菌している MRSAによる感染症を反復する患 者や，長年にわたり陽転化と陰転化を繰り返す患者もい るため, アウトカムと関連付けた評価が困難である.従っ て我々は AHR の使用量と本戦略のツールの一部である $\lceil$ Hand Hygiene Self-Assessment Framework 2010」 (以下「自己評価 $\mathrm{FW}\rfloor)^{18)}$ のスコアをプロセス評価とし て用いた。

\section{II 目 的}

重症心身障害児 (者) 病棟における「WHO 手指衛生 改善のための多角的戦略」を用いた介入の実践とその効 果について, 手指衛生剂使用量の推移, 耐性菌の院内新 規検出率の推移, および自己評価によるプロセス評価を 用いて検討した.

\section{対象と方法}

\section{I 研究期間}

2012 年 4 月 1 日〜 2017 年 3 月 31 日を全調査期間とし て，後方視的に検討を行った.

\section{AHR 使用量}

2012 年 4 月 1 日〜 2013 年 3 月 31 日の期間をベースラ イン, 2014 年 4 月 1 日〜2017 年 3 月 31 日を介入期間と し, 各年度の病棟毎の平均使用量の推移について検討し た.

\section{2 院内新規 2DRA}

2012 年 4 月 1 日〜2017 年 3 月 31 日の期間の検出率に ついて調査したが，2014 年 4 月 1 日以前には検出はな かったため, 2014 年 4 月 1 日〜2017 年 3 月 31 日の期間 での検出率の推移について検討した.

\section{3 自己評価 $\mathrm{FW}$ スコア}

2013 年度のスコアをベースラインとし, 2015 年度末, 2016 年度末のスコアの推移について検討した.

\section{II 対 象}

当院の 2 つの重症児（者）病棟 $\mathrm{A}, \mathrm{B}$ （各 60 床）を
対象とした。

介入前調査期間と介入期間 2014 年 4 月 1 日 2015 年 4 月 30 日の 1 病棟の 1 日あたりの平均職員数は 38 人/ 日, その内訳は医師 1 人, 看護師 20 人, 療養介助員 3 人，業務技術員 1 人，児童指導員 1 人，保育士 4 人，理 学療法士 6 人, 作業療法士 1 人, 臨床工学技士 1 人, で あった。病院職員外で, 病棟に設置している AHR を使 用する人員としては，ボランティア 1 人，特別支援学校 教諭 10 人であった. 2015 年 5 月 1 日から, 平均職員数 は 41 人/日で, 看護師 $22(+2)$ 名, 介助員 $4(+1)$ 人 となっている.

\section{III 項目の測定と評価}

AHR 使用の量的評価には「Guide to the Implementation of the WHO Multimodal Hand Hygiene Improvement Strategy」(以下「実施案内」) ${ }^{19)}$ と「自己評価 FW」 に基づき「AHR 使用量 $\mathrm{L} /$ 延べ入院患者日数 $\times 1000 」$ を 用いた。各病棟のリンクナース (Link Nurse : 以下 LN) が各種 AHR の払い出し本数を毎月集計し, それぞれの 1 本あたりの量を掛け合わせて合算しその月の払い出し 量を算出した。一月あたり払い出し量 $(\mathrm{L}) /$ その月の延 べ患者日数 $\times 1000$ を「AHR 使用量 L/1000 患者/日」と して算出した．現場に対しては「中小規模の医療機関向 けサーベイランス手順書」に従い, 払い出し量をLか ら mLに換算 $(\times 1000)$ し，当院で採用している AHR 製材の 1 プッシュ分の $1.3 \mathrm{~mL}$ で割った值/その月の延 べ患者日数を「1患者 1 日あたりの手指消毒回数」とし て，フィードバックを行った．年度の評価には該当年度 の 4 月〜翌 3 月まで 12 ヶ月間の平均使用量を用いるこ ととし, 重症児 (者) 病棟 $\mathrm{A} / \mathrm{B}$ の值, および他の病棟 も含めた病院全体での值についても評価を行った。

過去に検出歴のない, 重症児（者）病棟の長期入院患 者から新規に発生した2DRA について, 感染診断用に 提出された検体だけでなく, 監視培養として提出された 検体も含めて評価を行った。 これらはすべて重症児(者) 病棟 $\mathrm{A}$ 病棟からの検出であったため, 検出率について は検出数/重症児 (者) 病棟 $\mathrm{A}$ の延べ患者日数 $\times 1000$ として算出した。

各年度間で一元配置分散分析を行い，有意差を認めた 場合にBonferroni 検定を用いて比較した．統計学的有 意水準は $5 \%$ 未満とした. 解析には SPSS 24.0 (IBM, Armonk, NY, USA）を用いた。

\section{IV プロセス評価}

プロセス評価には「自己評価 FW」を用いた。（表 1) 取り組み開始前の評価は 2013 年 10 月に実施した。取り 組み開始後の評価は, 2015 年度については 2016 年 3 月, 2016 年度については 2017 年 3 月に実施した。評価はい ずれも感染管理認定看護師 1 名とインフェクションコン トロールドクター 1 名が協議しながら行った. スコア化, 
表 1 自己評価フレームワーク

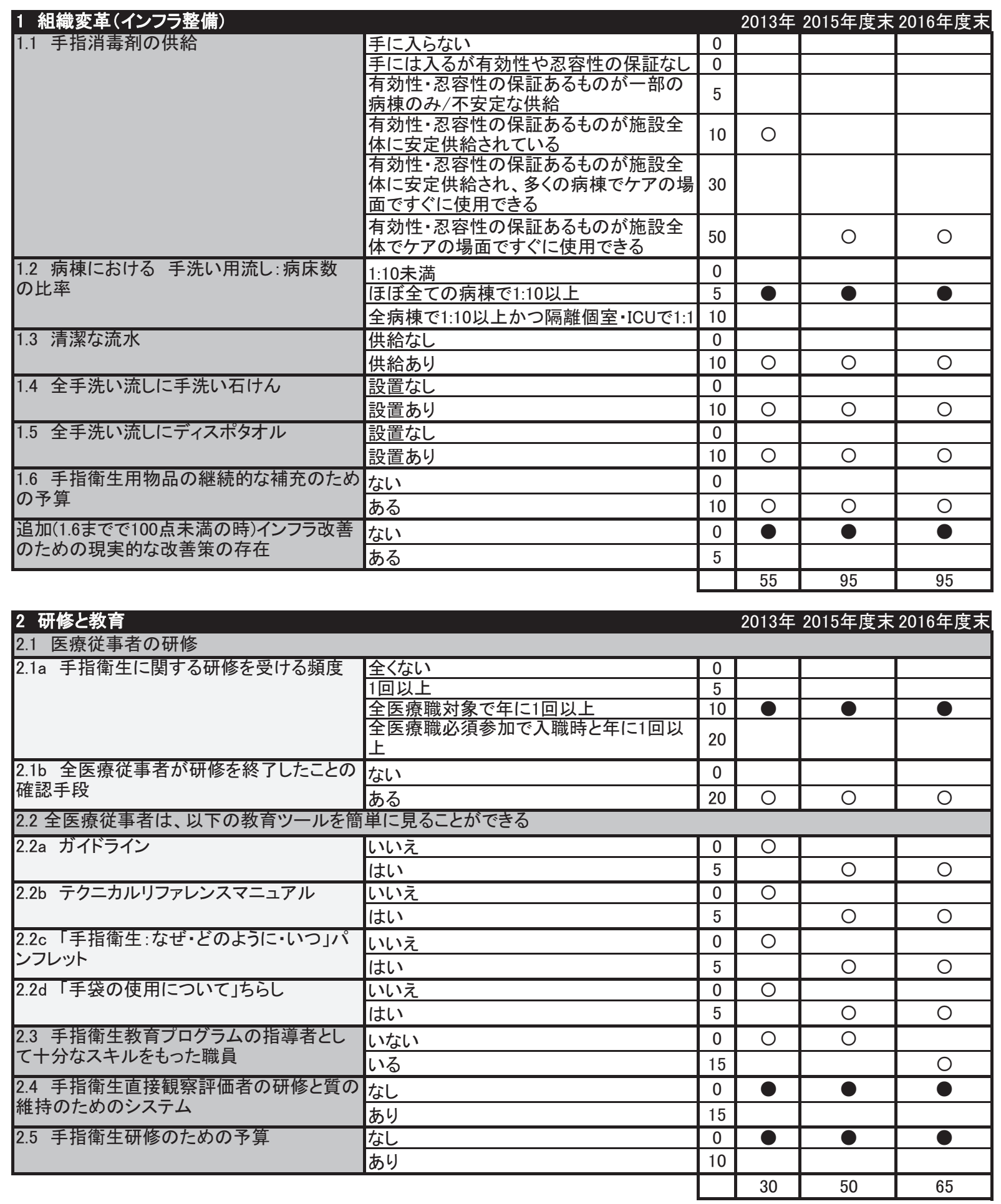


表 1 自己評価フレームワーク（続き）

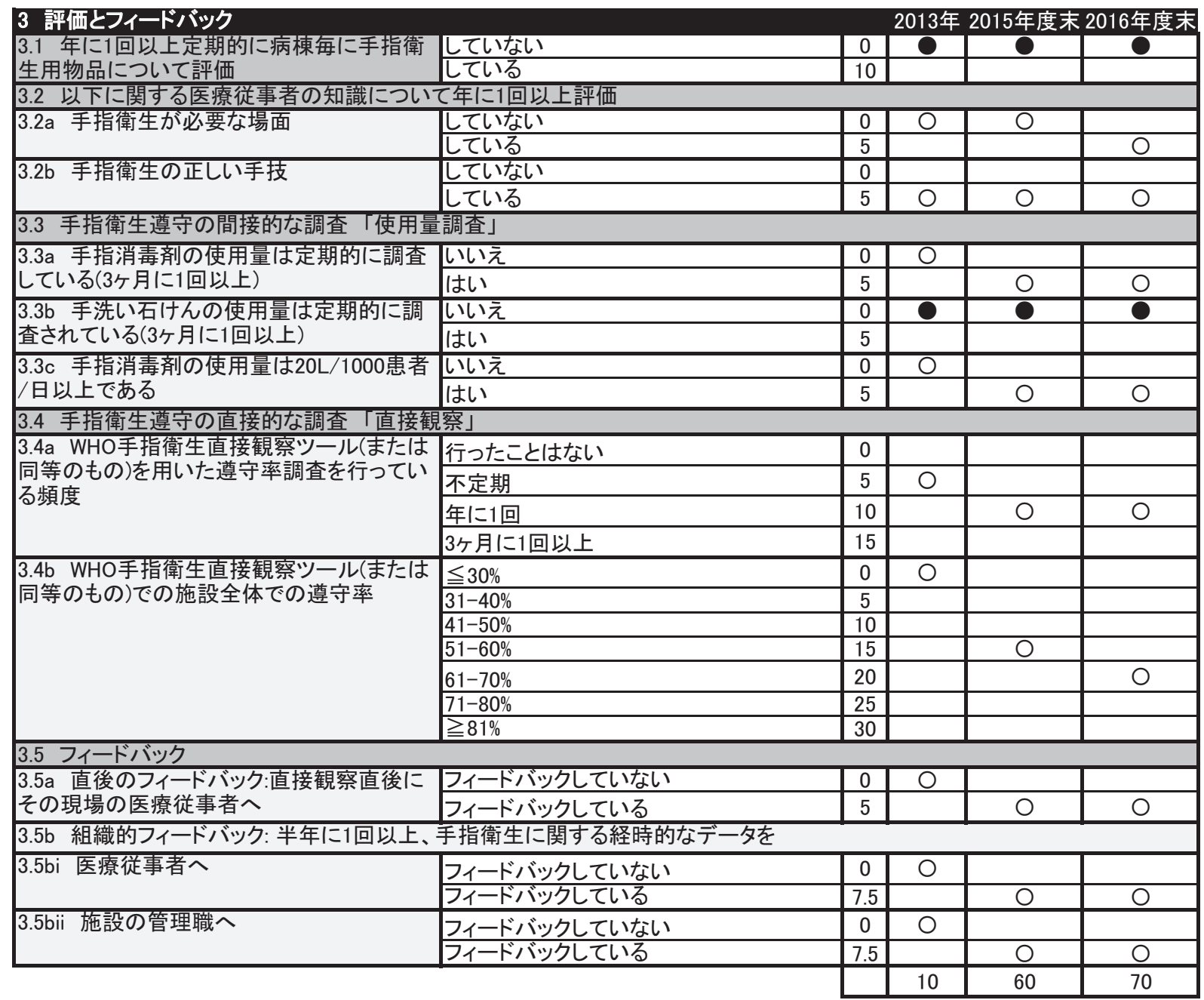

4 現場のリマインダー

4.1 以下のポスターの掲示

4.1a 手指衛生が必要な場面

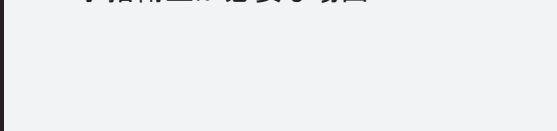

$4.1 \mathrm{~b}$ 手指消毒手順

4.1c 手洗い手順

4.2 掲示物が破損していないかの組織的な 評価および必要時貼り替えを行う頻度

4.3 手指衛生推進キャンペーンでの掲示は 上記と別に実施

4.4 病棟に手指衛生に関する情報のチラシ や冊子

4.5 施設内全般の現場に他の手指衛生リマ インダー(スクリーンセーバー・バッチ等)
2013年 2015年度末 2016年度末

\begin{tabular}{|c|c|c|c|c|}
\hline 掲示されていない & 0 & 0 & & \\
\hline いくつかの部署で掲示 & 15 & & & \\
\hline ほとんどの部署で掲示 & 20 & & 0 & 0 \\
\hline 全ての部署で掲示 & 25 & & & \\
\hline 掲示されていない & 0 & & & \\
\hline いくつかの部署で掲示 & 5 & O & O & o \\
\hline ほとんどの部署で掲示 & 10 & & & \\
\hline 全ての部署で掲示 & 15 & & & \\
\hline 掲示されていない & 0 & & & \\
\hline いくつかの部署で掲示 & 5 & & & \\
\hline ほとんどの部署で掲示 & 7.5 & 0 & & \\
\hline 全ての部署で掲示 & 10 & & 0 & 0 \\
\hline していない & 0 & 0 & $\mathrm{O}$ & \\
\hline 年に1回以上 & 10 & & & 0 \\
\hline 2-3ヶ月毎 & 15 & & & \\
\hline していない & 0 & $\mathrm{O}$ & & \\
\hline している & 10 & & $\mathrm{O}$ & 0 \\
\hline なし & 0 & $\mathrm{O}$ & $\mathrm{O}$ & \\
\hline あり & 10 & & & O \\
\hline なし & 0 & $\mathrm{O}$ & & \\
\hline \multirow[t]{2}{*}{ あり } & 15 & & $\mathrm{O}$ & $\mathrm{O}$ \\
\hline & & 12.5 & 60 & 80 \\
\hline
\end{tabular}


表 1 自己評価フレームワーク（続き）

\begin{tabular}{|c|c|c|c|c|c|}
\hline $\begin{array}{l}5 \text { 施設の姿勢(風土·文化) } \\
5.1 \text { 施設の手指衛生改善を推進するチーム }\end{array}$ & & & 013 & 5年) & 年 \\
\hline $5.1 \mathrm{a}$ チームの存在 & なし & 0 & & & \\
\hline & あり & 5 & $\mathrm{O}$ & $\mathrm{O}$ & $\mathrm{O}$ \\
\hline 5.1b チームのミーティング & 月に1回以上の開催なし & 0 & & & \\
\hline & 定期的に(月に1回以上)開催 & 5 & $\mathrm{O}$ & $\mathrm{O}$ & 0 \\
\hline 5.1c 積極的な手指衛生推進活動のための & なし & 0 & $\mathrm{O}$ & $\mathrm{O}$ & \\
\hline 活動時間の確保 & あり & 5 & & & 0 \\
\hline 5.2 施設の管理職による、手指衛生の改善を & 支持し支援するという意思表时 & & & & \\
\hline $5.2 \mathrm{a}$ 院長 & なし & 0 & 0 & & \\
\hline & あり & 10 & & 0 & 0 \\
\hline $5.2 \mathrm{~b}$ 診療科長 & なし & 0 & O & O & O \\
\hline & あり & 5 & & & \\
\hline 5.2c 看護部長 & な & 0 & 0 & & \\
\hline & あり & 5 & & 0 & 0 \\
\hline 5.3 施設全体で5月5日に手指衛生推進 & なし & 0 & 0 & & \\
\hline キャンペーン」を行う明確な計画 & あり & 10 & & 0 & 0 \\
\hline 5.4 医療現場における 手指衛生リーダー」 & & & & & \\
\hline 5.4a 手指衛生チャンピオン」: 推進の責任 & なし & 0 & $\mathrm{O}$ & & \\
\hline 者を任命するシステム & あり & 5 & & O & 0 \\
\hline 5.4b 手指衛生ロールモデル」: 良きモデル & なし & 0 & $\mathrm{O}$ & $\mathrm{O}$ & \\
\hline を識別·活用するシステム & あり & 5 & & & 0 \\
\hline 5.5 患者の手指衛生改善への参加 & & & & & \\
\hline 5.5a 手指衛生の重要性について、患者への & なし & 0 & $\mathbf{O}$ & O & $\overline{0}$ \\
\hline お知らせ(例:パンフレットなど) & あり & 5 & & & \\
\hline 5.5b 患者が参加する、病院公認のプログラ & なし & 0 & O & $\mathbf{0}$ & $\mathbf{0}$ \\
\hline & あり & 10 & & & \\
\hline 5.6 & & & & & \\
\hline 5.6a 手指衛生 $\mathrm{e}-$-ラーニングツール & なし & 0 & 0 & 0 & \\
\hline & あり & 5 & & & 0 \\
\hline 5.6b 施設の手指衛生「年間目標」の設定 & なし & 0 & $\mathrm{O}$ & & \\
\hline & あり & 5 & & 0 & 0 \\
\hline 5.6c 手指衛生改善に関する現場での効果 & なし & 0 & 0 & $\mathrm{O}$ & \\
\hline 的なエ夫を他の部署とシェアするシステム & あり & 5 & & & 0 \\
\hline 5.6d 手指衛生に関する継続的な情報発信 & なし & 0 & 0 & 0 & \\
\hline （ニュースレター、会議など） & あり & 5 & & & $\mathrm{O}$ \\
\hline 5.6e 個人の手指衛生行動に関する責任を & なし & 0 & O & $\mathbf{0}$ & $\overline{0}$ \\
\hline 問うシステム & あり & 5 & & & \\
\hline $5.6 f$ 新入職者に対するバデイシステム & なし & 0 & O & $\mathbf{0}$ & $\mathbf{0}$ \\
\hline & あり & 5 & & & \\
\hline & & & 10 & 45 & 70 \\
\hline
\end{tabular}

WHO Hand Hygiene Self-Assessment Framework 2010 p2-6の表を著者が日本語訳し、当院のデータを追記した

スコアを上げる余地があるにも関わらず、全くスコアが上がっていない項目は

スコアを上げる余地がない、もしくは、本とりくみ期間中にスコアが上がった項目は○

レベル判定の方法は「自己評価 FW」に示されている通 りに行った。

統計学的評価は, 「III 項目の測定と評価」に記載の 方法で実施した。

\section{V 手指衛生順守率向上プログラムの立案}

2009 年に発表された本戦略は「The step-wise approach」(以下「段階的アプローチ」), 「The five components of the WHO multimodal hand hygiene improvement strategy」(多角的戦略の 5 つの構成要素 以下「5 つの構成要素」), そして広く知られている「The five mo- ments for hand hygiene in health care」(以下「手指衛 生 5 つの瞬間」）の 3 要素で構成されている。（図 1）ま た，本戦略を実行するにあたり実際に活用できるッール が「The implementation tool kit」(以下「実施のため のツール集」）として提示されている。（表 2)これには $\lceil$ 実施案内」,「Template Action Plan」(以下「行動計画 テンプレート」) 20 22) を含む「general tools」(以下「全 般的ツール」) や, 各種リマインダーや教育ツールなど を含む「5 components (tools of the key components)」 (以下「5つの構成要素ツール」) が含まれる. 


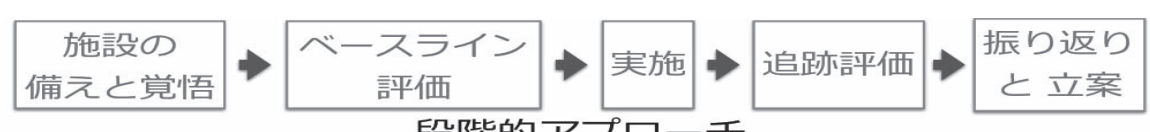

段階的アプローチ

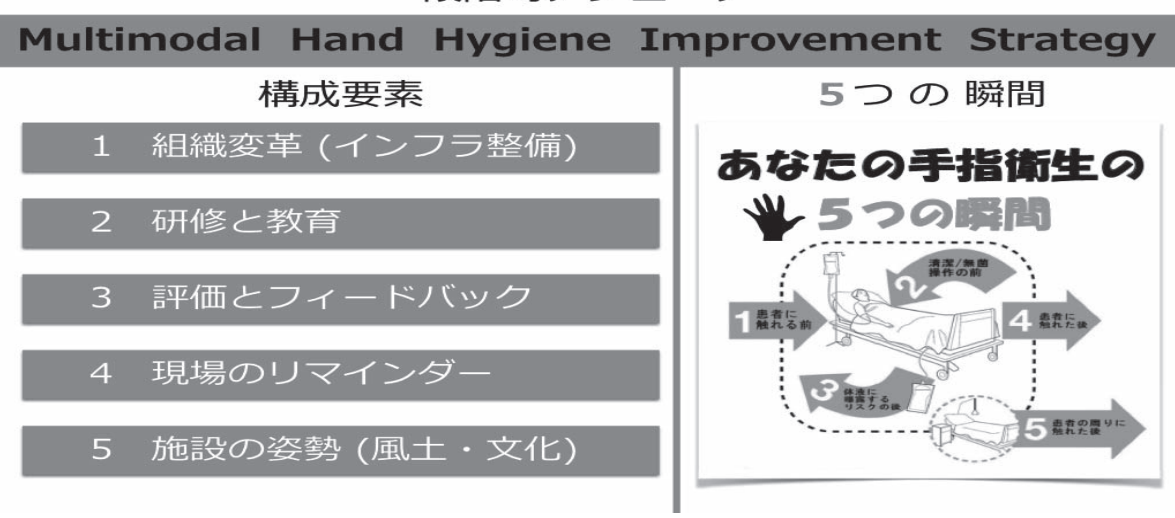

WHO Guide to the Implementation of the WHO Multimodal Hand Hygiene Improvement Strategy p10 の図を，著者がー部改変し、日本語訳した

図 1 WHO 手指衛生多角的戦略 全体の概要図

表 2 実施のためのツール集

\begin{tabular}{|c|}
\hline 医療施設における手指衛生ガイドライン 般 \\
\hline 手指衛生多角的戦略「実施案内」 \\
\hline 衍動計画テンプレート \\
\hline
\end{tabular}

\begin{tabular}{|c|c|c|c|c|}
\hline $\begin{array}{l}1 \text { 組織変革 } \\
\text { (インフ整備) }\end{array}$ & 2 研修と教育 & $\begin{array}{l}3 \text { 評洒と } \\
\text { フィードバック }\end{array}$ & $\begin{array}{l}4 \text { 現場の } \\
\text { リマインダー }\end{array}$ & $\begin{array}{l}5 \text { 施設の姿勢 } \\
\text { (風土 - 文化) }\end{array}$ \\
\hline 病棟インフラ調査 & $\begin{array}{l}\text { 施設の手指衛生改善推 } \\
\text { 進担当者のためのス } \\
\text { イド }\end{array}$ & $\begin{array}{l}\text { テクニカルリファレン } \\
\text { スマニュアル }\end{array}$ & 5つの瞬間ポスター & $\begin{array}{l}\text { 管理者に手指衛生改善 } \\
\text { を推奨するお手紙 }\end{array}$ \\
\hline \multirow{2}{*}{$\begin{array}{l}\text { 手指消毒剂の導入計画 } \\
\text { と原価計算 }\end{array}$} & \multirow{2}{*}{$\begin{array}{l}\text { 教育担当者, 観察者, 医 } \\
\text { 療従事者のための研修 } \\
\text { スライド }\end{array}$} & 直接観察記録用紙 & \multirow{2}{*}{ 手指消毒手順ポスター } & \multirow{2}{*}{$\begin{array}{l}\text { 管理者に手指衛生改善 } \\
\text { 計画への支持と支援を } \\
\text { 求めるお手紙 }\end{array}$} \\
\hline & & 遵守率計算方法 & & \\
\hline $\begin{array}{l}\text { 手指消毒剂現地製造案 } \\
\text { 内推奨処方 }\end{array}$ & 教育動画 & 病棟インフラ調査 & 手洗い手順ポスター & $\begin{array}{l}\text { 手指衛生改善への患者 } \\
\text { 参加のための案内 }\end{array}$ \\
\hline $\begin{array}{l}\text { 石けん: 手指消毒剂使 } \\
\text { 用量調査 }\end{array}$ & $\begin{array}{l}\text { 教育動画と組み合わせ } \\
\text { るスライト }\end{array}$ & \begin{tabular}{|l} 
石けん: 手指消毒剂消 \\
費量調査
\end{tabular} & $\begin{array}{l}\text { 「手指衛生:なぜ·ど の } \\
\text { ように・いつ」パン } \\
\text { レット }\end{array}$ & $\begin{array}{l}\text { 改善を続けるために追 } \\
\text { 加できる取り組み }\end{array}$ \\
\hline \multirow{6}{*}{$\begin{array}{l}\text { 手指消毒剂忍容性調査 } \\
\text { プロトコル } 1 \text { 使用中/導 } \\
\text { 入予定製剂の評価 } \\
\text { 手指消毒剂忍容性調査 } \\
\text { プロトコル } \\
\text { 比較 }\end{array}$} & $\begin{array}{l}\text { テクニカルリファレン } \\
\text { スマニュアル }\end{array}$ & 医療従事者の認識調査 & $\begin{array}{l}\text { 「命を守る：きれいな } \\
\text { 手で」スクリーンセー } \\
\text { バー }\end{array}$ & $\begin{array}{l}\text { 「命を守る：きれいな } \\
\text { 手で」プロモーション } \\
\text { DVD }\end{array}$ \\
\hline & 直接観察記録用紙 & 管理者の認識調査 & & \\
\hline & $\begin{array}{l}\text { 「手指衛生:なぜ·ど の } \\
\text { ように・いつ」パン } \\
\text { レット }\end{array}$ & \begin{tabular}{|l|}
$\mid$ 医療従事者の手指衛生 \\
知識調査
\end{tabular} & & \\
\hline & $\begin{array}{l}\text { 「手袋の使用につい } \\
て 」 ち ら し ~\end{array}$ & $\begin{array}{l}\text { 手指消毒剂忍容性調査 } \\
\text { プロトコル } 1 \text { 使用中/導 } \\
\text { 入予定製剂の評価 }\end{array}$ & & \\
\hline & 5つの瞬間ポスター & $\begin{array}{l}\text { 手指消毒剂忍容性調査 } \\
\text { プロトコル } 2 \text { 製剤間の } \\
\text { 比較 }\end{array}$ & & \\
\hline & FAQ & データ入カ分析ツール & & \\
\hline
\end{tabular}

WHO Guide to the Implementation of the WHO Multimodal Hand Hygiene Improvement Strategy p9 の表を著者が日本語訳した 


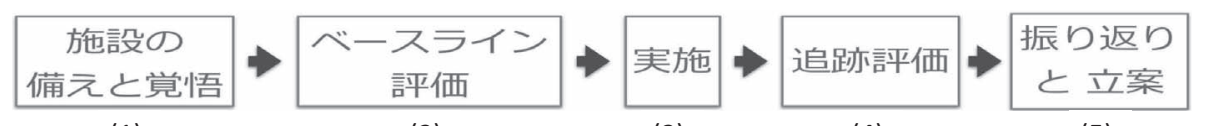

(1)

(2)

(3)

(4)

(5)

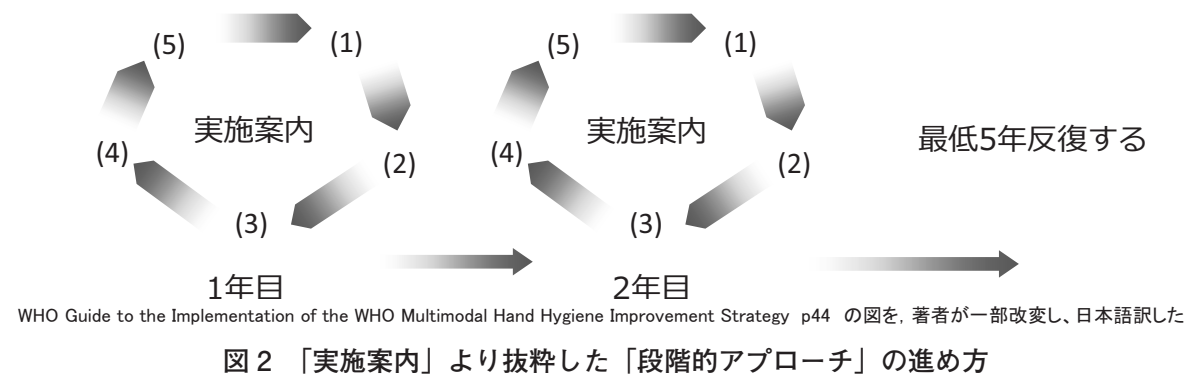

我々は, 具体的な実施方法が詳細に記載されている「実 施案内」に沿って，一部改変しながら「段階的アプロー チ」（図 2）に準じてプログラムの立案を行った.「自己 評価 FW」（表 1）を用いてベースライン評価を行った 後「行動計画テンプレート」を参考に「実施のためのツー ル集」を活用するプログラムを作成した. これまで当院 における手指衛生の取り組みは皆無であったため, 初年 度は感染制御チーム (Infection Control Team：ICT) 主 導で開始し, 2 年目以降現場主体の活動に徐々に移行し た後, 手指衛生改善を病院全体で継続する文化への移行 をめざすこととした．これを効果的に行うため，米国の 疾病管理センター (Centers for Disease Control and Prevention：CDC）の「結核施設内感染対策ガイドラ イン (2005) 」33) を参考に, まずシステム, 次にハードの 整備を優先的に行い, 各職員が取り組み易い環境を整え ることとした。

2 年目以降は各年度末に取り組み内容や AHR 使用量, 直接観察の結果などをふり返り, 次年度の目標設定や取 り組み計画を立案した。

具体的に計画・実施した主な取り組みを, 構成要素別 に以下に示す.

\section{1 組織変革（インフラ整備）}

$\lceil$ System Change」という名称の構成要素だが, 内容 はAHRの配備等インフラ整備が主となっている. 全職 種が必要時に AHR ヘアクセスできる環境をつくること に重点をおいた。

\section{- AHR の配付と設置}

自己評価 FW 項目 1.1 「全ての医療従事者がケアの現 場（point of care）ですぐに AHR を使用できる」こと を重視し, 取り組み初年度から, 日常的に多数の患者に 濃厚に接する機会の多い看護師, 介助員, リハビリ職員, 保育士，および希望する医師に AHR 個人携帯用ポーチ を配布した. 隣接する特別支援学校の教諭, ボランティ ア，面会家族，および AHR を携帯していない医師が入 退室時に使用できるよう，以前から全病室前に設置して
いた AHR はそのまま残したが，その利用をさらに促進 させるため, 2 年目以降順次自動ディスペンサーへと変 更した。

\section{- 複数種類の AHR の導入}

WHO ツールには AHR 製剤比較評価用のツールが用 意されているが, 現在国内で購入できる製剤については 機能的にもコスト的にもさほど大きな差はない.しかし AHR に含まれる保湿成分は製品により様々であり，製 品による手荒れの程度は個人により大きく異なる。この ため自分にあったものを使用できるよう， 2 年目からは 複数種類から選択できるようにした.

\section{2 研修と教育}

全職種が継続的に研修を続けられるシステムの整備, および現場のリーダーによるスタッフ教育が容易となる システムとハードの整備を優先した.

\section{・研修会の対象と開催の工夫}

ICT 主催の手指衛生に関連する研修会は, 医療職だ けではなく, 全職員対象の研修として毎年行った。曜日 や時間をずらし，昼の休憩時間带で昼食持参も可とする 形式も含め, 同じ研修会を 6〜9 回開催した. 特に初め の 2 年間は, 早期に多くの職員に確実な知識が身につく よう全職員必須参加とした.

・オリジナル教育ツールの開発とアクセス拡大

$\lceil 5 つ の$ 構成要素ツール」内に教育動画が用意されて いるが, 会話がフランス語で, 医療現場が当院の現状と かけ離れているためわかりにくいとの意見が多かった. このため, 保育士, 介助員, ボランティアといった専門 的な医学的知識を持たない人にも理解しやすいように, 当院独自でオリジナル手指衛生教育動画を作成した．初 年度は, 全職種が基本を一目で理解できるように，シン プルな動画をICT 出演で作成した． 2 年目はコメディ カル部門も含めた現場スタッフが出演し, それぞれの部 署で問題と捉えている場面について, 独自の手指衛生動 画を作成した。

自己評価 FW 項目 2.2 は「全ての医療従事者が教育 
ツールをすぐに使用することができる」となっている. 我々は，現場リーダーがスタッフに教育を行いやすいよ う，また場所や時間を選ばず必要なツールを確認・活用 できるように，動画も含めた多様なツールをすべてまと めて電子カルテシステム内に収載し, 自由に閲覧, 印刷 などができるようにした

3 評価とフィードバック

当院では本取り組みを開始するまで, 継続的な手指衛 生評価は全く行っていなかった。このため, ベースライ ン評価における「自己評価 $\mathrm{FW}$ スコアも非常に低かっ た。「実施案内」では, 取り組み開始の際に本要素を整 備することが重要である, と述べられているため, 効果 的に評価・フィードバックができるシステムの構築を優 先して行った。 また同時に，この実施者の育成も行った.

\section{・質的評価（直接観察）}

本研究期間中は，どの場面で遵守率が低いか，および, 職種毎の傾向を把握することを目的として実施した．年 2 回の手指衛生強化月間中に ICT が中心となって各部 署の感染対策を推進する現場のリーダー（感染対策マネ ジャー：Infection Control Manager 以下 ICM, 詳細に ついては後述）らと共に直接観察を行った. iPadを活 用してその評価結果を現場の管理者らに速やかにフィー ドバックし，詳細なコメントは後日現場に返した． 2 年 目以降, 各部署の ICM も自ら直接観察が行えるように, 現場で on the job training 方式で教育を行った.

\section{- 量的評価 (AHR 使用量調査)}

以下の目的で実施, 利用した. 1）年度ごとの目標值 達成度評価, 2) 部署によるトップダウンの指導強化の ため看護師長会での報告データ，そして 3) 目標值 $(100 \%$ 遵守）と比較した遵守率の目安. 初年度は 1) の目的で, ICT が調查し LN 会での共有のみに留めたが， 2 年目以 降は現場の自主的改善を促すために，2），3）の目的に も利用し, 各病棟 LN が每月自部署について調査を行い, 自分たちの手指衛生の実施状況をふり返り, 修正するこ とを促した， 2 年目からは，AHR 使用量結果を毎月看 護師長会に提出し, 結果が思わしくない部署には看護部 長から指導するという仕組みを構築した.

\section{4 現場のリマインダー}

院内全ての部署において, 全職種が目にすることがで きるよう，初年度から AHRにとりつけるリマインダー, 手指衛生キャンペーンポスターなどを配付した。いずれ にも必ず「5つの瞬間」を示した.

\section{5 施設の姿勢（風土・文化）}

当院にとっては非常に重要な構成要素と認識し, 初年 度から重点をおき戦略的に取り組んだ。本要素について は,「自己評価 FW」の項目を数多く活用した。

\section{・病院全体として改善に取り組むという共通認識と目 標の共有}

組織のバックアップなしでは手指衛生の取り組みは成 功しない2 ${ }^{24)}$.また, 「手指衛生改善は『ICTのよびかけ る自主的な活動』ではなく, 病院全体の課題として行う こと」というコンセンサスを得る必要がある。このため 取り組みを開始するにあたり，WHO 手指衛生多角戦略 =「病院全体の取り組み」として進めることを, 最終決 定機関である院内感染防止対策委員会で宣言した。この 際に「5つの構成要素ツール」に含まれるテンプレート を参考に院長を初めとする各部署の管理者へ手紙を出し， 院長の全面的な推進支援の確約も得た。 さらに自己評価 テンプレート項目 $5.6 \mathrm{~b}$ を参考に「病院全体で同じ目標 に向かって頑張る」という連帯感や，「具体的な目標達 成に向けて頑張る」という動機づけを得るために，看護 部と協同して院内共通の AHR 使用量の数值目標の設定 を行った。

・院内感染対策を推進する現場リーダーの任命

自己評価 FW 項目 5.4 で提唱されている内容だが, 現 場の職員また多職種のそれぞれが主体的にとりくむこと の重要性は過去の文献でも報告されている25.26).

2013 年度当時唯一の現場の感染対策担当者であった 「リンクナース (LN)」は, 実際に現場でリーダーシッ プをとる立場にはまだない若いスタッフが多かった。ま た看護職以外の職種には「感染対策を推進する」役割を もつ担当者が存在していなかった。このため感染対策を 推進する現場のリーダーとして「感染対策マネジャー (ICM)」を, すべての職種から一名ずつ初年度から任命 した。

自己評価 FW では各現場に「リーダーシップをとる 推進責任者」と共に「ロールモデル」をおくことも推奨 されている．初年度と 2 年目は LN に本役割を期待した。 しかしこの場合看護部以外の部署にロールモデルが存在 しえず，LN 以外でも適格と思われる看護師も見られる ようになってきたため，3 年目に全職種から投票で「手 指衛生マスター」を選出した。「手指衛生強化月間」キャ ンペーンの中で, 全部署でお互いの手指衛生実施状況を みて 1 数名互選し, 名札に手の形のマークをつけ誰が 見ても「マスター」とわかるようにした。 これにより身 近な「お手本」として仲間から認識され，本人もそれを 自覚して手指衛生を実践する「ロールモデル」が全部署 に在籍することとなった.

・定期的なキャンペーンの実施

自己評価 $\mathrm{FW}$ 項目 5.3 で年に 1 回のキャンペーンが提 唱されている. 我々は病院全体で集中して手指衛生改善 に取り組む期間として，「手指衛生強化月間」を毎年 5 月と 10 月に設けた。 これは ICM 中心の活動とし, ICT と ICM による直接観察, 強化月間ポスター掲示, 手指 
表 3 年度毎の「5つの構成要素ツール」「自己評価フレームワーク」項目の活用

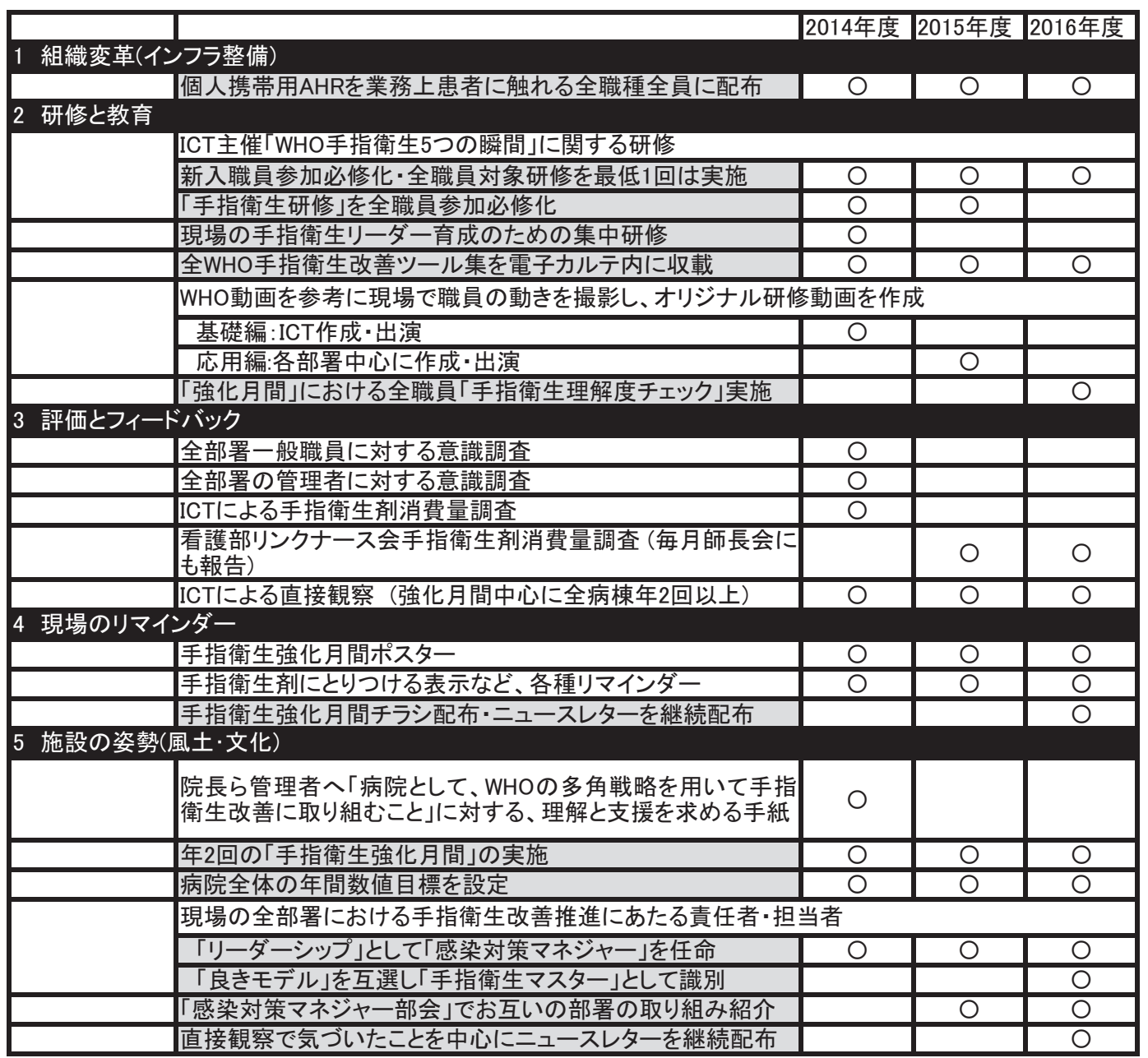

白の行は「5つの構成要素ツール集」、網掛けの行は「自己評価フレームワーク」に記載されている項目

衛生研修会開催を毎年行った。この他にも各部署独自の 手指衛生改善の取り組みの実践と ICM 部会での情報共 有, ICT 主導の「理解度チェック」や「手指衛生マス ター選出」などもキャンペーンの一環として行った. 特 に 5 月の ICM 部会は新年度の目標や課題を発表し「病 院全体で手指衛生に取り組む」ことを再確認する場とし た. 年 2 回としたことで直接観察機会も増え, 5 月に見 つかった課題の解決状況を 10 月のキャンペーンの際に 確認することが可能となった．直接観察のリアルタイム のフィードバックは「手指衛生強化月間」として取り組 んでいる現場職員の問題意識の向上や効果的な取り組み の実践に慗がると考えた.

実際に活用した「5つの構成要素ツール」や「自己評

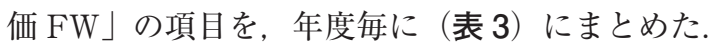

VI 段階的アプローチ

「実施案内」partIII（p39-）に，5つの段階それぞれ について具体的な実施スケジュール案が提案されている.
WHO は（図 2) に示す「段階的アプローチ」の中でも 「(5) 立案」の段階を重視している。このため今回我々 は前年度の取り組みの実績の評価を行い，これを元に少 しずつ内容を変化させながら次年度の計画を立案し, 年 単位で取り組みを継続した．当院の現状に合わせて改変 した「当院オリジナル 段階的アプローチの進め方」を

(図 3) に示す.

\section{VII 倫理的配慮}

本研究は当院の 2017 年 3 月における倫理審査委員会 にて承認を得た。

\section{結果}

\section{プログラムの実践}

（図 3）にあるように（立案 $\rightarrow$ ) 覚悟 $\rightarrow$ 実施 $\rightarrow$ 評価 $\rightarrow$ 立案 $\rightarrow$ とう順序で, 3 年間継続的に取り組みを実施し た. 毎年度末の 3 月にその年度について（4）評価を行 い,これをもとに（5）次年度の目標・計画を立案した。 


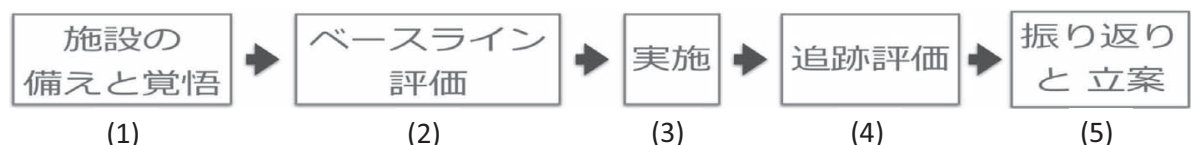

(1)

(2)

(3)

(4)

(5)

\begin{tabular}{|c|c|c|c|c|}
\hline 覚悟 & (1) & $-(1)$ & $(1)$ & (1) \\
\hline 立案 & (5) & $\sqrt{(5)}$ & $\sqrt{(5)}$ & \\
\hline 評㑑 & $(4)$ & (4) & (4) & \\
\hline 実施 & (3) & (3) & (3) & \\
\hline & 2014年度 & 2015年度 & 2016年度 & \\
\hline
\end{tabular}

2年目からは、前年度の(4)評価をそのまま新年度の (2)ベースライン評価として活用した このため、2年目以降は、図2)のWHOオリジナル版よりステップを1つ少なく改変している 年度末に(4)年度評価を行い、これをもとに(5)次年度の目標や計画を立案した。

5月の手指衛生強化月間で新年度の目標や計画を発表し(1)覚悟·宣言して(3)実施にそのまま進んだ

図 3 当院オリジナル版「段階的アプローチ」の進め方

新年度 5 月の手指衛生強化月間で（1）覚悟・宣言とし て年度の目標・計画を発表し，そのまま（3）実施に進 んだ。年度末の（4）評価が次年度の（2）ベースライン 評価となるため，2 年目以降は（図 2) の WHO オリジ ナル版とは異なり（2）の段階を省いている．以下はそ の実際を記述するが，本文中の番号は（図 3）の番号に 対応する。項目別の年度経過については（表 4）にまと めた。

\section{4 年度}

(1) 覚悟

7 月に院長に本取り組みへの理解と支援を求める手紙 を出し, 支援の確約を得た. その後同月の院内感染防止 対策委員会で本取り組みを開始することを決議した。取 り組み開始年度であるため, ICT が主体となってシス テム・ハードの整備を優先して行うこととした.

(2) ベースライン評価

2013 年度の「自己評価 $\mathrm{FW}$ の得点は 117.5 点, 手指 衛生レベルは「不十分レベル」であった. 同年の病院全 体における AHR 使用量年間平均值は $4.4 \mathrm{~L} / 1000$ 患者/ 日，重症児（者）病棟 $\mathrm{A} / \mathrm{B}$ における $\mathrm{AHR}$ 使用量は 4.2 / $2.8 \mathrm{~L} / 1000$ 患者/日であり, これを当院の取り組み開始 前のベースライン評価とした。直接観察の結果職員全体 の手指衛生実施率は 5 つのどの場面でも等しく低く, 特 に特徴的な傾向はみられなかった.

以上の評価をもとに「手指衛生レベル：不十分レベル」 の「行動計画テンプレート $ل^{20)}$ の内容を中心に，年度の 病院全体の目標值を 2013 年度の病院全体における AHR 使用量の約 2 倍, $8 \mathrm{~L} / 1000$ 患者/日と設定して取り組み を開始することとした。

(3) 実施

1 組織変革 (インフラ整備) $: 7$ 月から全職種に AHR の個人携带ポーチ配布を行った。

2 研修と教育：8月に全ての WHO ッール集を電子
カルテ端末から簡単にアクセスできるように整備した. 8 月～9 月にかけて手指衛生研修会を全職員必須参加研修, および，現場リーダー育成のための集中研修も行った。 ICT メンバーが出演するオリジナル手指衛生教育動画 を作成した

3 評価とフィードバック：取り組み開始にあたって 全職員の意識調査を 8 月〜 9 月にかけて行った。 5 月と 10 月に手指衛生強化月間の中で ICTによる直接観察と フィードバックを実施した。4月から毎月 ICT が各病 棟の AHR 使用量を調査し LN 会でフィードバックした.

4 現場のリマインダー：7月から全部署の AHR に「5 つの瞬間」のリマインダーをとりつけた． 5 月と 10 月 の手指衛生強化月間に, 手指衛生推進ポスターを全部署 で掲示した。

5 施設の姿勢（風土・文化）：4月から「感染対策マ ネジャー（ICM）部会」を発足させた。本年度から毎年 5 月と 10 月に手指衛生キャンペーンとして「手指衛生 強化月間」を実施した。

\section{(4) 年度評価}

重症児（者）病棟 $\mathrm{A} / \mathrm{B}$ における $\mathrm{AHR}$ 使用量は 10.1/ $5.5 \mathrm{~L} / 1000$ 患者/日であり，2013 年度のベースライン值 と比較して 2 倍程度増加した。病院全体の AHR 使用量 は $10.3 \mathrm{~L} / 1000$ 患者/日であり年度目標は達成できた。直 接観察の結果，全ての職種において「1の瞬間」の実施 率が低いことが明らかとなった，取り組み全体の評価を ICT で行ったところ, 手指衛生改善の取り組みは ICT のみが中心となり，ICM 部会においても各 ICM からの 具体的な発案などがそしいという問題点が示された。 AHR 使用量は倍増したが遵守率としては 1 2 割程度と 推定され, 手指衛生改善の取り組みが現場レベルまで浸 透したとは言えない状況と評価した。

（5）立案

2015 年度は, 手指衛生改善の取り組みを「ICT が主 


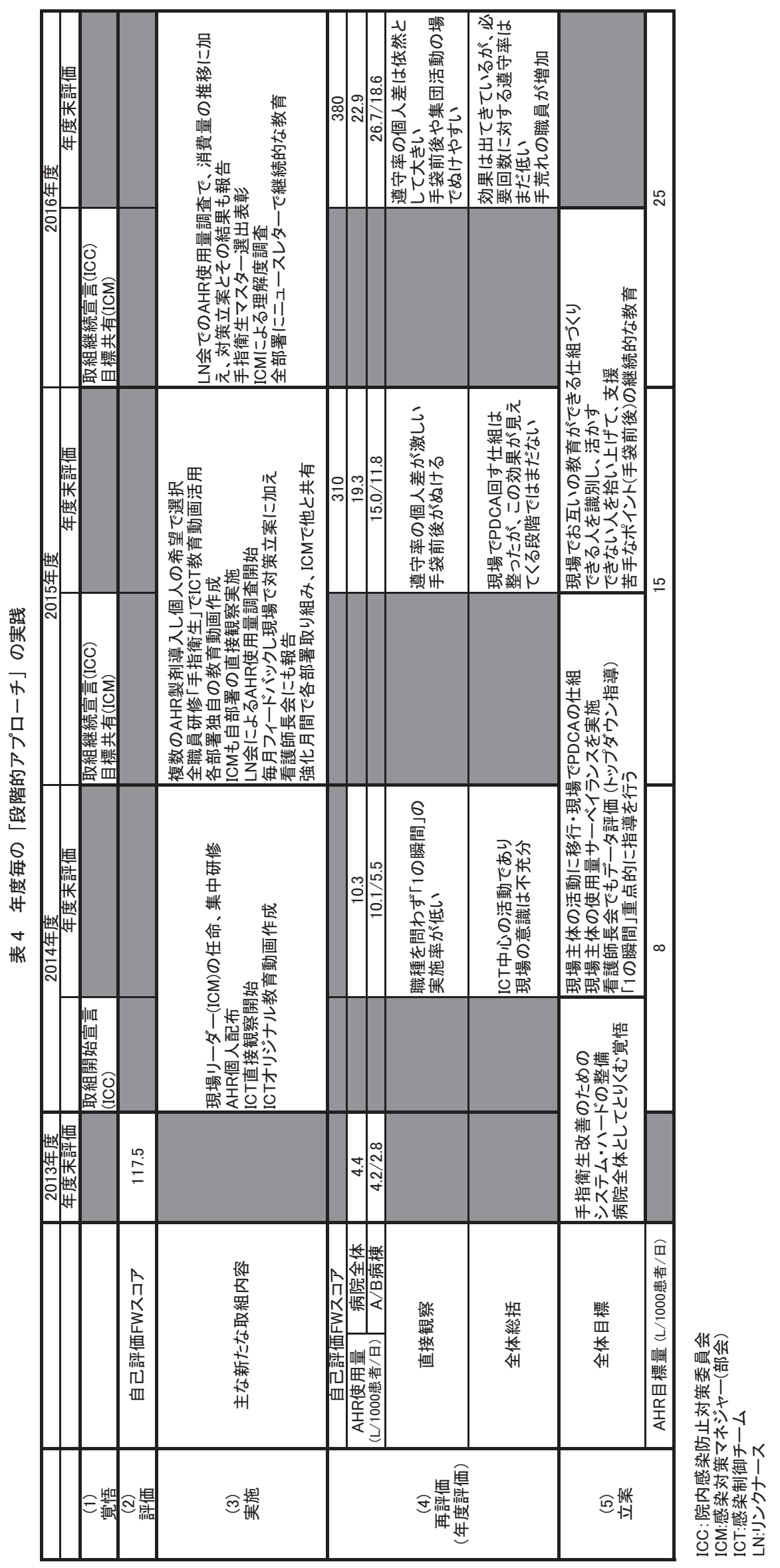


体」から「現場でPDCA が回せる」活動へと移行する ことを目標とした．教育は「1の瞬間」に重点をおくこ ととした. 2015 年度の病院としての AHR 使用量の目標 はPittetらがMRSA 院内伝播を抑制するのに効果的 だったと報告していた $15 \mathrm{~L} / 1000$ 患者/日 ${ }^{12)}$ とした。

\section{5 年度}

(1) 覚悟

4 月の院内感染防止対策委員会で本年度も本戦略に取 り組むことを決議した， 5 月の ICM 部会で，前年度末 に立案した年度目標を共有した。

\section{(3) 実施}

1 組織変革 (インフラ整備)：それまで使用していた ゲル状製剤に加えアロマつき, 泡状など, 複数種類の AHR を導入し, 各自が自分の好みや肌に合わせて選択 できるようにした。全職種に個人携帯ポーチ配布を行う とともに，医師には小ボトル入りの泡状 AHR をリール つきで配付した。

2 研修と教育 : 5 月に「手指衛生」についての院内 感染対策研修会を，全職員必須参加として実施した。こ の中で前年度作成した ICT 主演の教育動画を活用した。 また，各部署が主体の教育動画を新たに作成し，全オリ ジナル教育動画を電子カルテ内に収載した。

3 評価とフィードバック：5月と 10 月の直接観察の 機会に, ICTによる ICM の直接観察 on the job training を実施した。各部署の AHR 使用量は前年同様 4 月から 毎月 LN が調査し, 結果を現場にフィードバックすると ともに，看護師長会で報告した.

4 現場のリマインダー：リマインダーは通年とりつ け，5月と 10 月の手指衛生強化月間に手指衛生推進ポ スターを全部署で揭示した。

5 施設の姿勢 (風土・文化) : 5 月と 10 月に研修会 直接観察・ポスター揭示を中心とした「手指衛生強化月 間」を実施した。強化月間では現場中心の活動への移行 を意識し，ICM を中心とした各部署独自の取り組みを 促し, 翌月の部会にて各部署における取り組みとその成 果をお互いに紹介した。

\section{(4) 年度評価}

重症児（者）病棟 A/B における AHR 使用量は 15.0 / 11.8 L/1000 患者/日であり, ベースラインの 348/437\%， 前年度からの増加率は 48.5/114.5\% であった. 病院平均 AHR 使用量は 19.3 L/1000 患者/日であり，2015 年の年 度目標は達成できた。直接観察では，全ての職種におい て，手袋装着前後など，特定の場面における実施率が低 いといった問題点が明らかとなった。また看護師は特に, できる人とできない人の差が激しい傾向がみられた．年 度末の時点の「自己評価 $\mathrm{FW}$ スコアは 310 点で, 手指 衛生レベルは「中間」レベルとなった。現場でPDCA を回すシステムは整い, 手指衛生がかなり身についてい
る職員も散見されるようになった，しかし，重症児(者) 病棟全体としての遵守率は 2〜3 割程度と推定され，実 際に現場でPDCA が回り，その効果が見られる段階で はまだなく，全職員に手指衛生が浸透したとは言えない 状況と評価した。

(5) 立案

2016 年度は「できる人とできない人の差が大きい」こ とに着目し，「できる人」を活かし，「できない人」を拾 い上げて効果的な教育を現場で行う体制をつくることを 目標とした。 またキャンペーンの狭間の期間にも継続的 な教育的な働きかけを行うことを ICT の目標とした. 全 体としては「全職員が手指衛生を当たり前のように実施 すること」を目標とした. 2016 年度の病院としての AHR 使用量の目標は 2015 年度に達成した量を参考に, $25 \mathrm{~L} /$ 1000 患者/日とすることとした。

\section{6 年度}

(1) 覚悟

4 月の院内感染防止対策委員会で本年度も本戦略に取 り組むことを決議した，5月の ICM 部会で，前年度末 に立案した年度目標を共有した。

(3) 実施

1 組織変革 (インフラ整備)：前年度と同様の取組に 加え, 全病室入り口に設置してある AHRの自動ディス ペンサー化が完了した.

2 研修と教育：5月にオリジナル動画を活用した手 指衛生研修会を全職員対象研修として行った。また全職 員必須参加の院内感染対策研修のテーマを「標準予防策」 とし，この中でも手指衛生の「5つの瞬間」を取り入れ た. 直接観察の結果共通の弱点と判明した場面について は，6月から月に 1 回ペースを目標に ICT 発信のニュー スレターを全部署に配付し，教育的な働きかけを継続し た. 自部署で理解度が低い職員を見つけ出す目的で, 各 ICM が「強化月間」の活動の一つとして「理解度チェッ ク」を行った．全部署の全職員を対象に 9 月に「5つの 瞬間」の 5 つがどの場面かを記述，10月に当院独自の 動画を用いて手指衛生を実際に行うべき瞬間がどこか時 間を記載する形でチェックを行った，集計，および理解 度が低いと判明した職員の教育を ICM の職務とした.こ の教育には，オリジナル動画の活用や，「手指衛生マス ター」とペアを組んでの on the job training 等が推奨さ れた。

3 評価とフィードバック：直接観察は前年度と同様 の頻度，方法で継続した．LN 会での AHR 使用量報告 は, 前年度までは数值の推移だけが報告されていたが, 本年度より自部署でのふり返り評価, 対策立案, 実際に 行った手指衛生の取り組みなどについても発表, 意見交 換を行った。

4 現場のリマインダー：前年度と同様, リマインダー 
表 5 自己評価フレームワーク スコアと手指衛生レベル

\begin{tabular}{|c|c|c|c|}
\hline & 2013年度 & 2015年度末 & 2016年度末 \\
\hline 構成要素 & 小計 & 小計 & 小計 \\
\hline 1 組織変革(インフラ整備) & 55 & 95 & 95 \\
\hline 2 研修と教育 & 30 & 50 & 65 \\
\hline 3 諲価とフィードバック & 10 & 60 & 70 \\
\hline 4 現場のリマインダー & 12.5 & 60 & 80 \\
\hline 5 施設の姿勢(風土·文化) & 10 & 45 & 70 \\
\hline 合計スコア & 117.5 & 310 & 380 \\
\hline 平均スコア & 23.5 & 62 & 76 \\
\hline
\end{tabular}

\begin{tabular}{|c|c|}
\hline 合計スコア(範囲) & 手指衛生レベル \\
\hline $0 \sim 125$ & 不十分 \\
\hline $126 \sim 250$ & 必要最低限 \\
\hline $251 \sim 375$ & 中間(強化されている) \\
\hline $376 \sim 500$ & 先進的(浸透している) \\
\hline
\end{tabular}

WHO Hand Hygiene Self-Assessment Framework 2010 p7 の一部を抜粋し、著者が日本語訳し、当院のデータを追記した

とポスターを利用した。

5 施設の姿勢 (風土・文化)：前年度と同様，5月と 10 月に研修会・直接観察・ポスター揭示を中心とした 「手指衛生強化月間」を実施し, 翌月に各部署で取り組 みを共有した，楽しく手指衛生を実施できる風土をつく ることを意識し，5月の強化月間では全部署のロールモ デルとしての「手指衛生マスター」の選出, 10 月の強 化月間では童謡などを活用した手技確認の推進活動も 行った.

\section{(4) 年度評価}

重症児（者）病棟 A/B における AHR 使用量は 26.7/ $18.6 \mathrm{~L} / 1000$ 患者/日まで増加した。病院全体平均 AHR 使用量は $22.9 \mathrm{~L} / 1000$ 患者/日であり, 年度目標には届 かなかった．直接観察の結果を解析したところ集団活動 の場面では 1 の瞬間の未実施が多い, 個人携帯している と 1 回量が不充分な場合が多い，また前年に引き続き手 袋装着前後の実施率が低い, といった傾向が明らかと なった. 年度末時点の「自己評価 $\mathrm{FW」スコアは} 380$ 点, 手指衛生レベルは「先進的」レベルとなった。 ICMを 中心に, LN や手指衛生マスターが加わることで, 現場 単位での PDCA が回り始めたと評価された部署が見ら れた。この一方, 必要手指衛生回数が多い現場, 例えば 重症児 (者) 病棟や筋ジストロフィー病棟は, 業務量調 査から算出された予測される AHR 使用量は約 50-65 L/ 1000 患者/日であったが，実際の使用量はその 3〜4 割 程度であると評価された。手荒れが悪化した職員が増え てきているとの報告があった.

(5) 立案

それぞれの部署で本来実施されるべき手指衛生回数を 意識し，これに近づけることを目標とした。また，より 一層現場中心で取り組む意識を強める働きかけをしてい くこととした，病棟での業務量調査に基づくと，100\%
遵守に必要な AHR 量は平均約 $50 \mathrm{~L}$ と算出され，最終 的にはこれが目標量となる。2016 年度は目標量 $25 \mathrm{~L} /$ 1000 患者/日まで達成できなかったが, 少しでもこの目 標量に近づけるため次年度の病院としての AHR 使用量 の目標は $30 \mathrm{~L} /$ 患者/日とすることとした。手荒れ対策 として, 皮膚保護剤の導入を検討することとした。

プロセス評価：自己評価フレームワーク（FW）

手指衛生レベルを示す FW スコアは，2013 年：不十 分レベルの 117.5 点であったが， 2015 年度 : 中間レベル の 310 点, 2016 年度末 : 先進的レベルの 380 点へと改 善した. 2013 年に比較して, 2015 年度末 $(\mathrm{P}=0.013), 2016$ 年度末 $(\mathrm{P}=0.001)$ ともに有意に平均スコアの上昇を認 めた。（表 5)

要素毎のスコアは, 2013 年, 2015 年度末, 2016 年度 末，の順に 1 組織変革（インフラ整備）については 55 点, 95 点, 95 点, 2 研修と教育については 30 点, 50 点, 65 点, 3 評価とフィードバックについては 10 点, 60 点, 70 点，4 現場のリマインダーについては 12.5 点, 60 点, 80 点, 5 施設の姿勢（風土文化）については 10 点, 45 点, 70 点, とそれぞれ推移した. 各点数の項目毎の内 訳については，表 1）に示した。

AHR 使用量・院内新規発生 2 系統耐性アシネトバク ター（2DRA）検出率の推移

AHR の年間平均使用量は重症览（者）病棟 A で 2.9 （2012 年） $\rightarrow 4.2 （ 2013$ 年) $\rightarrow 10.1 （ 2014$ 年) $\rightarrow 15.0 （ 2015$ 年) $\rightarrow 26.7 \mathrm{~L} / 1000$ 患者/日（2016 年）, 同 B で $2.2 \rightarrow 2.8 \rightarrow$ $5.5 \rightarrow 11.8 \rightarrow 18.6 \mathrm{~L} / 1000$ 患者/日と, 両病棟とも2014 年 度以降で有意に増加していた（各々 $\mathrm{P}<0.05 ）$ 。

重症児（者）病棟 $\mathrm{A}$ における院内新規 2DRA の年間 検出率は 0.32 (2014 年) $\rightarrow 0.18$ （2015 年） $\rightarrow 0 / 1000$ 患者/ 


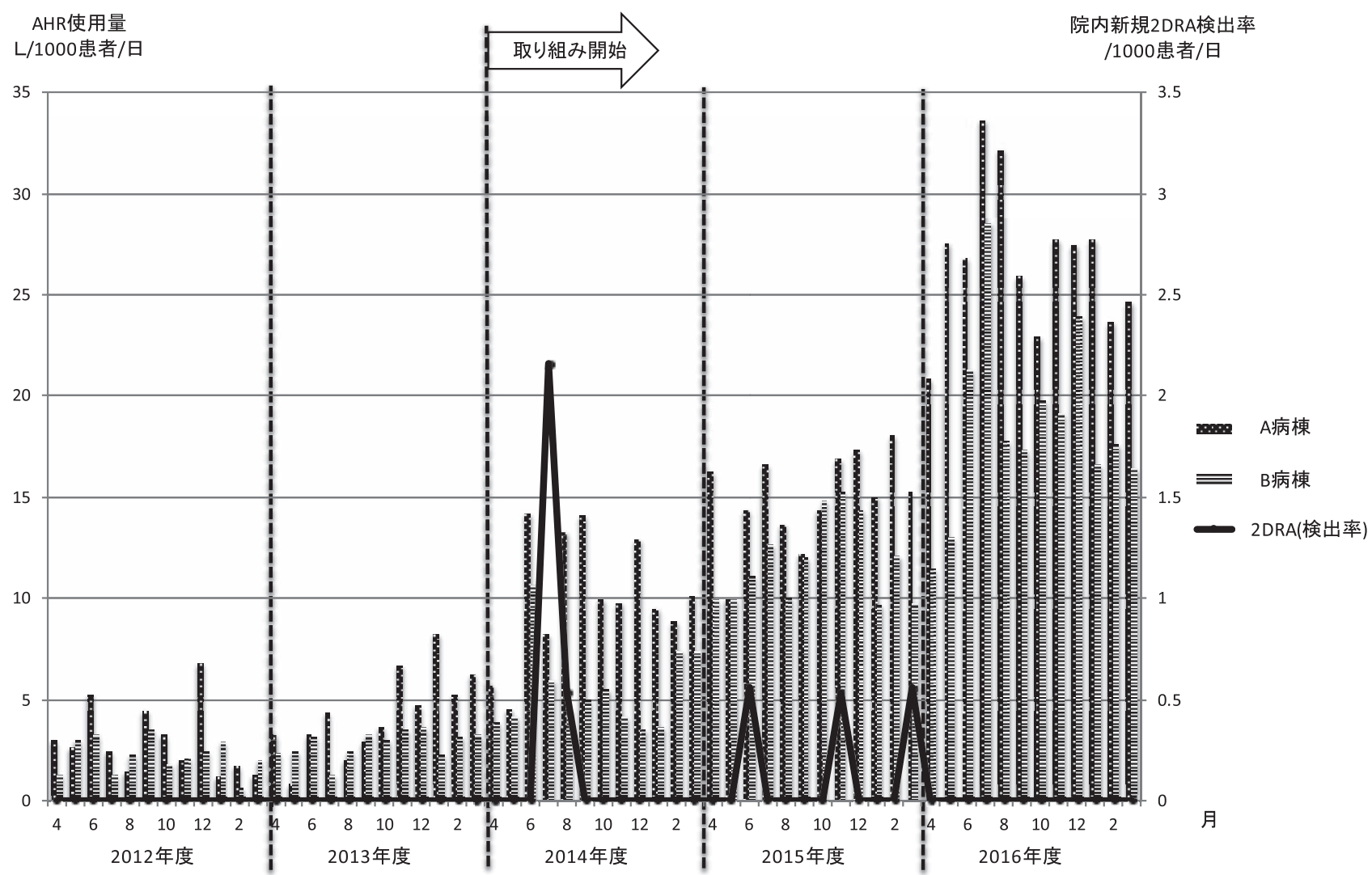

図 4 AHR 使用量・院内新規発生 2 系統耐性アシネトバクター（2DRA）検出率の月間值の推移

日（2016 年）と減少したが, 差は有意ではなかった（P $=0.241)$. なお, 検出された 2DRA の薬剤感受性結果は, すべて同一のパターンであった。

AHR 使用量, およびの 2DRA 検出率の月間の值の推 移について（図 4）に示した.

\section{考察}

重症児（者）病棟は「重症児の生命と生活を守る」以 外にも「療育の提供」「生命・生活の質を考慮した生活 の場」としての機能と役割を合わせもつため, 一般病棟 と比較して家庭的な風土がある ${ }^{27)}$. 感染対策の視点から は集団生活, 流れ作業的なオムツ交換や介助入浴など病 原体の伝播リスクが高く, 多数の人工呼吸器が稼働する 高度医療の場であるなど，多剤耐性菌がアウトブレイク しやすい環境でもある.

多剂耐性菌が広く世界に蔓延する現在「家庭的な風土」 だけでは重症児（者）病棟の患者の生命と生活を守るこ とは困難であり，患者に関わるすべての人が手指衛生を 当然のこととして行う「安全風土」を根付かせる必要が ある.そのためには医師や看護師だけでなく、コメディ カル, 非医療職など様々な教育背景をもつ全スタッフが 手指衛生の重要性を理解し, 主体的に実践できるための 教育や体制が必要である。この実現を目指し, 我々は
$\lceil\mathrm{WHO}$ 手指衛生多角的戦略」を参考に，3 年間多角的 かつ組織的に手指衛生の改善に取り組んだ.

手指衛生改善については WHO 以外からも CDCによ る「医療現場の手指衛生ガイドライン (2002)」以下「CDC 手指衛生ガイドライン 」28) や, 米国感染管理疫学専門家 協会 (Association for Professionals in Infection Control and Epidemiology : APIC) による「感染予防のための 手指衛生プログラム (2015)」29) などのガイドラインが公 表されている.

$\lceil\mathrm{CDC}$ 手指衛生ガイドライン」の影響と効果について Larson らの報告 ${ }^{24)}$ がある. 彼女らは米国 CDC がガイド ラインを出しただけでは医療現場での手指衛生の大幅な 改善はみられず，その内容が実際に現場で反映されるた めには強力な組織的なサポートが必要であると述べてい る. 今回我々が活用した「WHO 手指衛生多角的戦略」 では，この組織的なサポートが最初から重視されている。

$\lceil\mathrm{WHO}$ 手指衛生多角的戦略」を活用した海外の報告 としては, 最近 Arntz ら ${ }^{10)}$ が「5つの構成要素ツール」 のうちの 2 研修と教育, 3 評価とフィードバック，4 現 場のリマインダー, 5 施設の姿勢に含まれる要素につい て 3 週間取り組んだ効果について報告している. Chen $ら^{11)}$ は「5つの構成要素ツール」と「段階的アプローチ」 を活用した取り組みについて報告している。彼らは過去 
にも手指衛生改善キャンペーンの実績がある施設におい て「段階的アプローチ」の 5 つのステップを 1 周実践し た効果について報告している。 しかし，我々のように手 指衛生改善の取り組みが全くなかった施設において，本 戦略を総合的に活用し, かつ毎年反復しながら継続的に 取り組んだ単施設からの報告は検索したかぎりでは見当 たらなかった。

一方久留野らは, 国内の多くの病院は手指衛生改善に 取り組んでいるものの「CDC 手指衛生ガイドライン」や $\lceil\mathrm{WHO}$ 手指衛生多角的戦略」に示されているような取 り組みを実践している病院は少ないと報告している ${ }^{30}$. その代り各施設で独自に考案されたプログラムを用いて, 複数年に渡り, 組織的, 多角的な手指衛生の改善に取り 組んだ報告が多数ある ${ }^{13 \sim 15)}$. 他にも半年〜 1 年程度の手 指衛生キャンペーンにおいて多角的な取り組みが行われ, この前後で改善がみられている16.17)。これらの中で久斗 $ら^{14)}$ と浜田ら ${ }^{17)}$ が我々と同様の方法で手指消毒剤の使用 量を算出していた，前者は $2.93 \rightarrow 8.58$, 後者は $5.8 \rightarrow 11.6$ L/1000 患者/日といずれも大きな増加を認めているが, 我々のように約 5 倍かつ WHO が目安として提示して いる $20 \mathrm{~L} / 1000$ 患者/日まで到達している報告はなかっ た.この他「WHO 手指衛生多角的戦略」を活用した国 内の報告では,「5つの構成要素ツール」に含まれる直 接観察法の活用 ${ }^{7.8)}$ や，「手指衛生の 5 つの瞬間」の考え 方を活用した研修9)の例などがある.

今回我々は, 多職種が患者に関わる病棟において一か ら手指衛生改善に取り組むにあたり，（図1）に示され る本戦略の 3 つの要素全体の活用が必要と考えた. 現場 の各職種が主体的に手指衛生に取り組む文化の酹成のた めには特に, このような綿密に練られた戦略に則って改 善をすすめることが, 最も効率的であると考える.この ため我々は, 独自の工夫を加えつつも, 取り組みの基本 となる本戦略に常に立ち返ることを意識し続けた。 $\lceil\mathrm{WHO}$ 手指衛生多角的戦略」を総合的に活用しかつ複 数年途切れることなく活動を続けたことで, 組織からの 支援, システムづくりそして現場主体の風土への移行す べてに段階的に取り組むことができた，特に我々が重視 したのは, WHO も強調している 4 追跡評価 (年度評価), 5 立案のステップであった，毎年度評価しそれに基づい て次の対策を立案することにより，一時的な改善で終わ ることなく, その時点に最適な目標設定や取組みが可能 となり持続的な改善が達成できたと考えられる。本論文 執筆の時点で 3 年間継続しているが, 最低でもあと 2 年 間は同様に継続していく予定である.

$\lceil\mathrm{WHO}$ 手指衛生多角的戦略」の総合的な活用ととも に, いくつかの点で我々独自の工夫も凝らした.「行動 計画テンプレート」では, 推奨しているツール類を各施 設の特性に合わせて適応させる必要性について指摘して
いる．また，各施設で実際に成果を得るために具体的を 何を実践するべきか判断するために，本テンプレートに 従うだけでなく「自己評価 $\mathrm{FW} 」$ 項目の点数の変化を詳 細に検討することも推奨されている.ささらに, ここでの 記述順で実施することを推奨しているわけではないこと も, 明記されている.「実施案内」の「段階的アプロー チ」の中でも具体的な実施スケジュールが提案されてい るが，これらも実際に全てそのままの形で適用すること は現実的ではない.

本戦略のツール類は, 現在の日本国内の状況に合わせ て作成されているものではない. 発展途上国でも活用で きるよう $\mathrm{iPad} の$ 使用等は想定されておらず，教育動画 はヨーロッパの病院で撮影されているため違和感を感じ る場面も多い. 我々は評価と報告を効率的かつ効果的に 実施するため, 紙への記録を極力控え $\mathrm{iPad}$ などのデジ タル機器を十分に活用した. これにより被評価者が自分 の行動を忘れないうちに即時フィードバックすることが 可能となり, LN や ICM などの負担が大幅に軽減され, 取り組みの継続につながったと考えている，教育では, 自施設を舞台にしたオリジナル動画を作成し, 現場のス タッフに浸透しやすい資材を提供した. 重症児（者）病 棟には，教育背景の異なる多職種が勤務する．寺島らは 同様の病棟において, 多職種に対して手指衛生の方法や タイミングを中心とした標準予防策についての教育的働 きかけは必要不可欠であると述べている5 . 本多らもコ メディカルに合わせた教育の工夫が有効であったと述べ ている ${ }^{31)}$ 。我々は WHO の教育動画を参考に, 実際の現 場で身近な職員が基本的な手指衛生を実施する，オリジ ナル教育動画を作成した。これにより専門的な医療知識 のない職種も, 重要なポイントが一目で理解できるよう になった．またコメディカルも含めて各部署で独自の動 画の作成に参加したことは, 病院全体としての手指衛生 文化の育成にもつながった。このように，各ツールを施 設の特性に合わせて改変することは, 本戦略の効果的な 活用のために必要であり, 場合によっては改変すること 自体も成果にも繋がりうると考えられる.

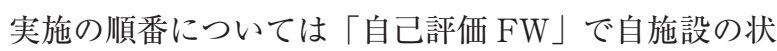
況を常に把握しつつ,「CDC 結核施設内感染対策ガイド ライン (2005)」の考え方に立ち返ることを意識した. 単 純に「取り組みやすいところ」から手をつけていくので はなく，システムを整備することを優先した． Marra らは一般病院において, 現場のスタッフ自身がどうした ら手指衛生を改善させることができるかについて話し合 い, 取り組んだ経験を共有することにより，手指衛生遵 守率が向上し院内感染が減少したと述べている ${ }^{25)}$. 田口 らはコメディカルを含めた多職種が院内感染対策に主体 的に関わることが重要であると述べている ${ }^{26)}$. 我々も同 様に, 現場職員が主体的に取り組む風土をつくることを 
最重要項目の一つと考え, この求心力となる現場のリー ダーをまず任命した。これに続いて各現場に身近な良き モデルを選出し，現場で効果的に対策をすすめるシステ ムを構築した。なお「現場リーダー」と「良きモデル」 は「自己評価 FW」に含まれる項目だが「行動計画テン プレート」,「実施案内」,「5つの構成要素ツール」には 記載されていない.「自己評価 FW」まで含めて本戦略 の全体を活用したことと，優先順位を熟考し定めたこと は，本戦略を進めるにあたって重要であったと考える。

手指衛生改善の取り組みの評価には従来, MRSA 感 染症発生数や MRSA 新規発生数を代表とするアウトカ ム評価が用いられている。しかし重症児（者）病棟では 長期保菌からの感染症の反復や, 陽転化と陰転化の反復 事例が多く，こういった評価が困難である．当院におい てもこれまで評価指標が定まらず，そのため評価も実施 できなかった。今回の取り組みで用いた評価指標（「自 己評価 $\mathrm{FW}$ ) は, 具体的な項目別のプロセス評価となっ ている.プロセスを個別に評価していくことにより目指 すものが明確に認識され，改善につながったと考えられ る.「自己評価 FW」は取り組み開始の段階では, 自施 設の足りない部分を知るためだけでなく, 始める必要性 について病院幹部の理解を得るためにも有用であった。 取り組み開始後, 年度末の 4 評価, 5 立案のステップで は, 未達成項目を確認して次年度の計画を立案するため に大いに活用することができた。本 FW のわかりやす い日本語訳を作成するために一定の時間と手間を要した が, これを用いて評価を行うことは大きな労力は必要で はなかった。 日頃から AHR 使用量や手指衛生遵守率を サーベイランスしている施設であれば，数十分程度でス コアを算出することは可能である。このわずかな時間と 労力で自施設の課題が見えてくるため, 多くの施設での 活用が望まれる。これまでの報告では，本スコアはある 地域における本戦略の浸透度合いを測る指標としては活 用されているが32.33), 遵守率との相関や, AHR 使用量と の相関をみた報告は見当たらない. 我々の研究では本ス コアが上がるとともに，AHR 使用量も着実に増加した。

「自己評価 $\mathrm{FW}$ スコアの伸び方は, 構成要素により 異なっていた．変化の傾向は 2 つに大別されたが，その 一つは初年度に 40 点以上大きく伸びてその後はあまり 変化のない $1 \cdot 3 \cdot 4$ であり, もう一つは毎年 $20 ３ 0$ 点 ずつ伸びが見られた $2 \cdot 5$ であった. 1 組織変革（イン フラ整備）に関しては，一般的な日本国内の病院であれ ば標準で装備されているものだけで数十点はスコアが期 待できる. 当院では取り組み 1 年目にAHR を全職種個 人携帯できるようにしたことだけで 40 点一気に上がり 95 点となった． 3 評価とフィードバックと 4 現場のリマ インダーに関しては, 取り組み開始前のスコアはわずか 10 点/12.5 点と低かった。 しかし取り組み開始時に多く
の項目を ICT 主導で改善させることができ， 1 年目に 両方とも 60 点まで上昇した。 これらの構成要素の中で 全く点数が上がっていないのは $3.1 「 一$ 年に 1 回以上の 定期的な手指衛生用物品の評価」3.3b「手洗い石けん使 用量の定期的な調査」4.1「手指消毒手順」の 3 項目で あるが, これらはすべて優先順位を考慮した結果, 本研 究期間内では未実施となっている。 なお， 3 に関しては 一部実際の AHR 使用量や遵守率の数字もスコア化され ているため, 遵守率が上がらないと満点は取れない仕組 になっている． 2 研修と教育，5施設の姿勢（風土・文 化）についてはICT だけでは改善できない項目も多く, 短期間で大きく点数を上げることは困難である，例えば 2.1a「全職員必須参加で入職時と年に 1 回以上手指衛生 に関する研修を受ける」2.4「手指衛生研修のための予 算」5.6f 「新入職者に対するバディシステム」など，手 指衛生以外の院内の教育システムにも関わる内容につい ては様々な部署との調整が必要になり, 今後の課題であ る。また $5.5 「$ 患者の手指衛生改善への参加」5.6e「個 人の手指衛生行動に関する責任を問うシステム」などに ついては, 日本の現在の医療風土の中で取り組むのは困 難と感じている。しかしこれらは必須の項目とは考えに くく, むしろ他の項目について着実に取り組みを進める ことの方が効果的であると考えられる.

「直接観察」については観察者のトレーニングも並行 して実施しているため, 本研究では直接観察から導き出 した遵守率を結果や取り組みの評価には採用しなかった。 「直接観察」によって算出される遵守率の数值には, 観 察者のレベルによる影響が大きいといわれている. 我々 は「直接観察」はあくまでもその場で観察できた弱点の 発見とそのフィードバック，といった形で「伸びしろ(潜 在的能力）を見つける」目的として活用し, 経年変化や 部署間の比較としては用いなかった. 現在は一定レベル の観察者が育成できたと考えられるため, 今後は「直接 観察」による遵守率の数字をデータとして活用し, 年度 毎や部署間の比較もしていく予定である.

本取り組みのきっかけともなった 2014 年 7 月から 8 月にかけての A 病棟における 2DRA の院内新規発生の 集積は, レスパイト目的で 2013 年の秋に短期間滞在し ていた患者による持ち込みを発端とした病棟内伝播の結 果と判断した。これまで $\mathrm{A}$ 病棟長期入院中の患者から 検出歴のない同一感受性パターンの菌が短期間で 2 名か ら検出されたため, 他にも保菌者がいることを疑って同 病棟の入院患者の監視培養を同心円状に対照者を拡大し ながら実施したところ，7月は合計 7 名， 8 月は 1 名陽 性者を検出した。その後一般的な感染症診断として提出 された培養検体からの検出もあったが，定期的に年に 3 回の監視培養を継続したため, これによる新規保菌患者 の検出もあった. 取り組みが進むと共に検出は漸減し, 
最終年度では年間新規院内発生数 0 となった。ただしこ の事象はもともと発生頻度が少なく観察期間も短期間で あるため, アウトカム指標とはなりえない。 また数ヶ月 毎の定期的な監視培養検体を含めた検出結果であるため, 1 ケ月毎の検出率の推移と AHR 使用量の増減について 直接の関連はほとんどないと考えられる。多剤耐性グラ ム陰性桿菌の伝播に関しては, 環境整備や器材の洗浄消 毒など手指衛生以外にも多くの要素が関わっており ${ }^{34)}$, 手指衛生の改善のみで新規院内伝播を防止できていると 言うことはできない. しかし一定レベル以上の手指衛生 が日頃から実施されるようになったことは，重症児(者) 病棟における多剤耐性菌の伝播リスクの低減につながっ ていると考えられ, 介入の効果を確認するためにも観察 と報告を継続することが重要である.

\section{結 論}

WHO 手指衛生多角的戦略の実践は, 重症児 (者) 病 棟における AHR の使用量増加に大変有用であった。「手 指衛生改善」には様々な手法があるが, 無秩序に取り組 むのではなく「自己評価 FW」を活用することで, 自施 設の課題を客観的に捉えられることができた. 中でも「安 全風土」が根付いていなかった当院において, 病院全体 でこの改善に着手したことにより大きな成果を上げたと 考えられた。全職種の現場リーダーを中心に改善に取り 組むシステムを構築できたことは, 多職種が関わる重症 児（者）病棟においては非常に大きな意味があった。ま た今回 2DRA の院内新規発生の集積を契機として手指 衛生改善に取り組んだが，一過性のキャンペーンに終わ ることなく「段階的アプローチ」を活用することで, 戦 略的かつ継続的に取り組むことができた.

手指衛生は標準予防策の中で最も重要であり, 全職員 が日頃から遵守できるようにしていかなければならない. しかしこの一方で, 様々な背景のある多くの施設がこの 困難さに直面している. 組織的, 多角的, 段階的, 継続 的なアプローチが求められるが, 独自にこれを立案する ためには大変な労力を要する.今回我々が実践した $\lceil\mathrm{WHO}$ 手指衛生多角的戦略」にはこれらの要素がすべ て包括されている．他の施設でも一部分の活用だけにと どまらず，本戦略の全体を活用することにより，効果を 上げることができると考えられた.

本論文の要旨は第 62 回環境感染学会（神戸市）で報告した.

利益相反自己申告：申告すべきものなし.

\section{文献}

1）佐々木征行：SMID データベースシステムからみた国立病 院機構の重症心身障害児者病棟の現状. 日重障誌 2011; 36
(1): $19-25$

2）岩崎裕治，家室和宏，宮野前健，倉澤卓也，益山龍雄，田 村正徳：療育施設における医療的ケアの必要な入所児 (者) およびNICU 長期入院児を含む受け入れ状沉等の実態調查. 日重障誌 2012; 37(1): 117-24.

3）湯浅正大, 中川栄二, 竹下絵里, 石山昭彦, 齋藤貴志, 齋 藤義朗, 他：重症児病棟および筋疾患病棟, 一般病棟にお ける抗菌薬耐性についての検討. 日重障誌２014; 39(3): 42733.

4）猪飼みつる, 織田麻希, 藤井龍哉: 集団療育におけるメチ シリン耐性黄色ブドウ球菌保菌児の隔離は必要か。環境感 染誌 2010; 26(4): 278-83.

5）寺島憲治，矢野久子，脇本寛子，金子和可子：小児長期療 養型施設における多職種職員のケア場面と手指衛生遵守に 関する検討. 環境感染誌 2015; 30(1): 33-42.

6) WHO: WHO Guidelines on Hand Hygiene in Health Care: http://who.int/infection-prevention/publications/hand-hygi ene-2009/en/. accessed June 26, 2017.

7）青木雅子, 北川洋子：NICUに㧍ける手指衛生遵守率向上 に向けて〜ビデオを使用した手指衛生の適切なタイミング の評価〜. 環境感染誌 2013; 28(2): 97-100.

8）鈴木さつき，村田弘美：直接観察法を用いた手指衛生と手 袋着脱のタイミングの遵守率上昇に向けた取り組み、環境 感染誌 2014; 29(4): 273-9.

9）山本容子, 岩脇陽子, 室田昌子, 滝下幸栄：病院職員を対 象としたパームスタンプ法を用いた手指衛生研修の有効 性一精神科単科病院に扮ける実践一. 環境感染誌 2015; 30 (4): $281-7$

10) Arntz PRH, Hopman J, Nillesen M, Yalcin E, BleekerRovers CP, Voss A, et al: Effectiveness of a multimodal hand hygiene improvement strategy in the emergency department. Am J Infect Control 2016; 44: 1203-7.

11) Chen JK, Wu KS, Lee SSJ, Lin HS, Tsai HC, Li CH, et al:: Impact of implementation of the World Health Organization multimodal hand hygiene improvement strategy in a teaching hospital in Taiwan. Am J Infect Control 2016; 44: 222-7.

12) Pittet D, Hugonnet $S$, Harbarth S, Mourouga P, Sauvan V, Touveneau S, et al: Effectiveness of a hospital-wide programme to improve compliance with hand hygiene. Lancet 2000; 356: 1307-12.

13）西岡達也, 岡本和恵, 井澤初美, 但馬重俊, 服部英喜 : 速 乾式手指消毒剂による手指衛生遵守率の向上への取り組み とその評価. 環境感染誌 2010; 25(1): 37-40.

14）久斗章広，宮良高維，森山健三，戸田宏文，山口逸弘，松 島知秀, 他: 手指衛生コンプライアンス指標の向上と MRSA 分離率の減少。環境感染誌 2011; 26(4): 243-8.

15）加藤豊範：手指衛生遵守率向上のための組織的な取り組み とその評価. 環境感染誌 2015; 30(4): 274-80.

16）本田順一, 小川節子, 野田順子, 大城暁子, 中野峰子, 安 達康子, 他 : 速乾式手指消毒薬消費量と MRSA 検出数. 環 境感染誌 2005; 20(4): 231-6.

17）浜田幸宏, 岡前朋子, 加藤由紀子, 久留宮愛, 高橋知子, 未 松寛之, 他 : 手指消毒薬倍増キャンペーン実施内容とその 効果. 環境感染誌 2016; 31(1): 32-5.

18) WHO Hand Hygiene Self-Assessment Framework 2010: ht tp://www.who.int/gpsc/country_work/hhsa_framework_ October_2010.pdf?ua=1. accessed June 26, 2017.

19) WHO Guide to the Implementation of the WHO Multimodal Hand Hygiene Improvement Strategy: http://www.wh o.int/gpsc/5may/tools/WHO_IER_PSP_2009.02_eng.pdf?ua $=1$. accessed June 26, 2017.

20) Template Action Plan for WHO Framework Inadequate/ Basic Results: http://www.who.int/gpsc/5may/PSP_GPSC 1_InadequateBasicWeb_Feb-2012.pdf. accessed April 16, 2018. 
21) Template Action Plan for WHO Framework Intermediate Results: http://www.who.int/gpsc/5may/PSP_GPSC1_Inte rmediateWeb_Feb-2012.pdf. accessed April 16, 2018.

22) Template Action Plan for WHO Framework Advanced/ Leadership Results: http://www.who.int/gpsc/5may/PSP_ GPSC1_AdvancedLeadershipWeb_Feb-2012.pdf. accessed April 16, 2018.

23） CDC：保健医療関連施設における結核感染予防ガイドライ ン 2005 (2006 年 9 月 6 日改訂) 翻訳 : 結核研究所ホームペー ジ小委員会 : http://www.jata.or.jp/rit/rj/2005guidelines.p df : 2017 年 6 月 26 日現在.

24) Larson EL, Quiros D, Lin SX: Dissemination of the CDC's Hand Hygiene Guideline and impact on infection rates. Am J Infect Control 2007; 35: 666-75.

25) Marra AR, Guastelli LR, Pereira de Araujo CM, Saraiva dos Santos JL, Lamblet LCR, Silva Jr M, et al: Positive Deviance: A New Strategy for Improving Hand Hygiene Compliance. Infect Control Hosp Epidemiol 2010; 31: 12-20.

26）田口洋子, 木村 紫, 五十里博美, 山下佳子, 星野守邦, 新 妻隆広：当院に打けるコ・メディカルスタッフに対する院 内感染予防に関するアンケート調査について. 環境感染誌 2008; 23(2): 151-4.

27）江草安彦監：重症心身障害療育マニュアル，第 2 版, 医歯 薬出版株式会社, 2005. p. 305-7.

28) Boyce JM, Pittet D: Guideline for Hand Hygiene in HealthCare Settings. Recommendations of the Healthcare Infection Control Practices Advisory Committee and the HI-
PAC/SHEA/APIC/IDSA Hand Hygiene Task Force. MMWR Recomm Rep 2002; 51(RR-16): 1-45.

29）Landers T: APIC 実践ガイド 感染予防のための手指衛生 プログラムガイド: http://www.goodhandhygiene.jp/wps/ wp-content/uploads/APIC_Guide.pdf. accessed June 26, 2017.

30）久留野紀子, 笠原 敬, 三笠桂一, 㫟浦一, 徳谷純子： 奈良県内の病院における手指衛生の状況に関するアンケー 卜調査. 環境感染誌 2013; 28(2): 91-7.

31）本多領子, 野村賢一：コメディカルにおける確認テストを 取り入れた勉強会効果. 環境感染誌 2011; 26(4): 234-8.

32) Allegranzi B, Conway L, Larson E, Pittet D: Status of the implementation of the World Health Organization multimodal hand hygiene strategy in United States of America health care facilities. Am J Infect Control 2014; 42: 224-30.

33) Bert F, Giacomelli S, Ceresetti D, Zotti CM: World Health Organization Framework: Multimodal Hand Hygiene Strategy in Piedmont (Italy) Health Care Facilities. J Patient Saf 2017 Jan 10; doi: 10.1097/PTS.0000000000000352. [Epub ahead of print].

34）日本環境感染学会多剂耐性菌感染制御委員会編：多殽耐性 グラム陰性菌感染制御のためのポジションペーパー 第 2 版. 環境感染誌 2017; 32(7): S1-S26.

〔連絡先：干289-0003 四街道市鹿渡 934-5 下志津病院小児科 鈴木由美 E-mail: yumiatwork@me.com]

\title{
Implementation of the World Health Organization Multimodal Hand Hygiene Improvement Strategy in SMID (Severe Motor and Intellectual Disabilities) Patients' Wards in Japan
}

\author{
Yumi Suzuki, Motoko Morino, Shigenori Yamamoto and Fuminobu SHINOZAKI
}

National Hospital Organization Shimoshizu Hospital

\begin{abstract}
Worldwide, the number of SMID (severe motor and intellectual disabilities) patients continuously in need of profound medical care, such as mechanical ventilation, are increasing. Infection control is of great importance since such patients have high risk of multidrug resistant organism colonization. On the other hand, SMID wards have an "at home" atmosphere, and various specialists, including co-medicals, helpers and child-carers are directly involved in taking care of patients. Therefore, it is difficult to permeate hand hygiene awareness throughout the staffs. The SMID wards in our hospital are not the exceptions and the consumption rates of AHR have been very low. After experiencing a two drugs resistant Acinetobacter baumanii (2DRA) outbreak in 2014, we started to implement the WHO multimodal hand hygiene improvement strategy in 2014, applying both "the step-wise approach" and "the five components of the WHO multimodal hand hygiene improvement strategy". The AHR consumption volume (mean value in a year) in ward A was 2.9 (2012), 4.2 (2013), 10.1 (2014), 15.0 (2015), and 26.7 L/1000patient/days (2016), and in ward B, 2.2, 2.8, 5.5, 11.8, 18.6 L/1000patient/days, respectively. Although "My 5 Moments for Hand Hygiene' approach" is the most famous component in this strategy, we found that "the step-wise approach" which shows how to initiate and renew periodically a comprehensive hand hygiene program, was also critical to make a smooth start, and to sustain the improvement of hand hygiene. In addition, for an effective improvement in hand hygiene, the prioritization and modification of the tools in "the five components of the WHO multimodal hand hygiene improvement strategy" and "Hand Hygiene Self Assessment Framework" was important.
\end{abstract}

Key words: hand hygiene, patients with severe motor and intellectually disabilities, WHO multimodal hand hygiene improvement strategy 